\title{
Intermittent Smoothing Approaches for Wind Power Output: A Review
}

\author{
Muhammad Jabir ${ }^{1}$, Hazlee Azil Illias ${ }^{1}$, Safdar Raza ${ }^{2}$ and Hazlie Mokhlis ${ }^{1, *}$ \\ 1 Department of Electrical Engineering, Faculty of Engineering, University of Malaya, 50603 Kuala Lumpur, \\ Malaysia; jabir.uet@gmail.com (M.J.); h.illias@um.edu.my (H.A.I.) \\ 2 Department of Electrical Engineering, NFC IET, Multan 60000, Pakistan; syedsafdar_raza@yahoo.com \\ * Correspondence: hazli@um.edu.my; Tel.: +60-12-646-7936
}

Academic Editor: Rui Xiong

Received: 12 September 2017; Accepted: 6 October 2017; Published: 12 October 2017

\begin{abstract}
Wind energy is one of the most common types of renewable energy resource. Due to its sustainability and environmental benefits, it is an emerging source for electric power generation. Rapid and random changes of wind speed makes it an irregular and inconsistent power source when connected to the grid, causing different technical problems in protection, power quality and generation dispatch control. Due to these problems, effective intermittent smoothing approaches for wind power output are crucially needed to minimize such problems. This paper reviews various intermittent smoothing approaches used in smoothing the output power fluctuations caused by wind energy. Problems associated with the inclusion of wind energy resources to grid are also briefly reviewed. From this review, it has been found that battery energy storage system is the most suitable and effective smoothing approach, provided that an effective control strategy is available for optimal utilization of battery energy system. This paper further demonstrates different control strategies built for battery energy storage system to obtain the smooth output wind power.
\end{abstract}

Keywords: intermittent sources; power fluctuations; voltage variations; frequency variations; power smoothing; battery energy storage system (BESS)

\section{Introduction}

Renewable sources that include wind and solar energies constitute a major share to fulfill world overall electricity consumption and demand [1]. These are rapidly originating as a source of electricity production according to IEO2016 Reference case as shown in Figure 1 [2]. Reports in [2] reflect that the total electric power generation from renewable resources increases by $2.9 \%$ annually, as a result, renewable energy contribution for world electricity generation will increase from 22\% in 2012 to $29 \%$ in 2040. 


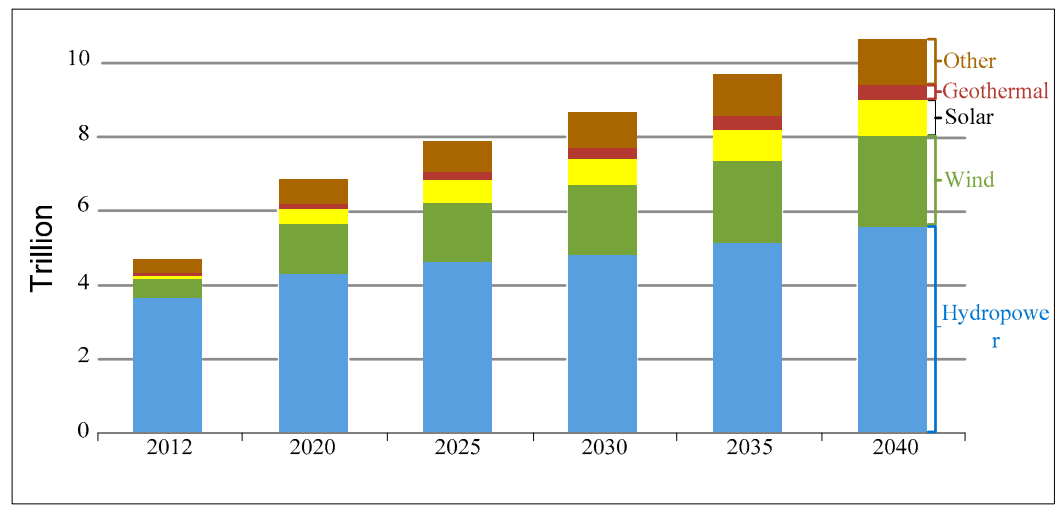

Figure 1. Total electricity production from fuel throughout the world from 2012 to 2040.

One of the most essential renewable sources for energy production is wind energy. It has distinct characteristics which differentiate it from other forms [3]. It was reported recently that cumulative global installation of wind energy conversion systems (WECSs) has reached $280 \mathrm{GW}$ [4]. It is expected that this amount will increase around 1900 GW by 2020 [5].

The total amount of electricity generated from wind is directly related to the speed of air. The wind penetration depends on the speed of wind, which varies day to day, hour-hour and even smaller duration of time (min and s). Determination of wind speed is essential to determine the amount of power produced by the wind generation system (WGS) and helpful in wind power smoothing. Wind speed can be determined by wind forecasting.

In consideration of the requirements of power system operation, the forecast is classified into four distinct directions: very short-term, short term, medium-term and long-term. To forecast wind, new technologies such as artificial intelligence (AI) and machining learning (ML) are applied. Some important and widely used technologies are multi-layer perceptrons (MLP) [6], radial basis function neural network (RBFNN) [7], recurrent neural networks (RNN) [8] and support vector regression (SVR) [9]. These techniques demonstrate the association with implicit ways and are often estimated as exhaustive. Numerical weather prediction (NWP)-based method [10] is another technique to forecast wind speed and usually is used for longer time frames. However, it needs to be upgraded to obtain more physical information. Hybrid methods [11-15] are very successful in wind power forecast, offering satisfactory accuracy.

Wind power output is directly proportional to the cube power of the wind velocity. It significantly fluctuates and does not remain constant due to intermittent nature of wind speed. Some issues associated with wind power fluctuations are described as follows [16]:

(1) Fluctuations of wind power resulted in the change in grid frequency.

(2) The reactive power of grid consumed by wind induction generator is related directly to the active power generation. Active power generation is varied by alteration in wind speed and hence absorbs reactive power, essential to voltage variation at the buses of the power grid.

(3) Both voltage flicker and frequency fluctuation yield low quality of power generation and results in instability issues of power generation system, particularly when there are high sensitive loads that cannot tolerate frequent fluctuation of high voltage and frequency variations.

Due to these negative impacts, some power utilities have imposed ramp limits to help restrain the power output from renewable energy generation. Puerto Rico Electric Power Authority (PREPA) has proposed that limitation of ramp-rate fluctuation produced from photovoltaic and wind turbines can be prevented up to $10 \%$ of rated capacity/minute [17]. Limitation of these voltage and frequency variation on the grid side can be reduced because of the imposed ramp-rate limits. It was explained in [18] that overvoltage is one of important and basic factors that limits wind farms and the capacity of distributed generation units in a radial distribution networks. It occurs when there is generation of 
high wind power with low load. Electrical distance of wind farm installation in correspondence to the substation determines the voltage rise. The most dangerous case of voltage rise includes lowest load as compared to the highest wind power generation.

Transmission lines and transformers in overloaded conditions are considered as a limiting factor for grid integration of wind farms in distribution grids [19]. Overloading usually relies on the thermal rating transformer and cables. Harmonic emission is also considered as a limiting factor in grid connection of inconsistent wind speed turbines, which are employing power electronics converters [20]. Power fluctuation increases due to aerodynamic power fluctuations are limiting features for connecting wind farms to weak distribution grids. Aerodynamic power fluctuation is generated because of wind shear, irregular wind speed and tower shadow effects. In a weak grid, power oscillation produces the worst voltage fluctuations along with remarkable line deficiencies. Voltage fluctuations due to aerodynamic power fluctuation can produce the worst power quality complications such as flicker in distribution systems. Power quality and flicker incidents due to wind energy were examined and inspected in [21,22]. Wind turbine units also contribute towards fault currents [23], which is another problem for grid integration systems consisting of wind power. Wind energy increases the grid fault level and the rating of switchgear becomes the limiting factor for wind integration.

Intermittent smoothing approaches are required in smoothing the output power fluctuations from wind energy. The intermittent smoothing methods are classified into two groups; (i) without utilization of energy storage devices and (ii) by utilizing energy storage devices [24,25]. Battery storage systems (BESSs) are the most suitable smoothing approach, provided that an effective control strategy is available.

The main objective of this review article is to review issues related to intermittent wind output connected to the grid and its mitigation methods. The first part of the paper explains potential problems that might occur due to wind output variability in grid connected mode. The second part highlights the methods for elimination of wind output power variations for individual wind generators. The discussion includes pitch control, flywheel, BESSs, superconductive magnetic energy storage (SMES), ultracapacitors or electric double layer capacitors (EDLCs) and maximum power point tracking (MPPT) power curtailment. From the comparative examination of diverse mitigation methods, it was found out that BESSs are the best option for overcoming the energy variation issue and hence the control strategy of BESS is also described briefly. The paper is arranged as follows: Section 2 describes the issues of wind power output fluctuations; Section 3 describes the methods of smoothing the wind power output fluctuations and Section 4 describes the control strategy of battery storage technology; Section 5 includes a discussion and Section 6 concludes the review.

\section{Problems Related to Intermittent Wind Power Sources}

The inclusion of wind-based energy sources into the utility grid causes power quality issues. The issues include voltage variation, unintentional islanding from the grid, reverse power flow and power fluctuations in grid connected systems and impact on utility frequency. Brief descriptions of these issues are given below:

\subsection{Voltage Fluctuation}

Voltage variation is the main issue associated with wind-based energy sources. The voltage of a wind connected grid depends on the output power of the wind and wind power depends on varying parameters that include the air density, wind speed and turbine characteristics. Voltage rises occur due to increases in wind active power injection to the utility grid due to a sudden rise in wind speed [26]. A sudden drop in wind speed causes a voltage drop in a wind connected utility grid. Induction generator-based wind sources consume reactive power and become the major cause of voltage drops in the utility supply. The influence of voltage variation is described in [27]. The voltage fluctuations lead to wind turbines being disconnected from the grid, which will result in breakdown of the power system. 


\subsubsection{Reverse Power Flow Due to Voltage Rise}

The power inserted into the grid depends on the wind speed. If the wind speed is higher, the power flow along with the voltage level at the substation increases. However, the voltage level may disobey the prescribed limitation in existence with the capacitor banks or voltage regulating devices that are usually installed at substations. This issue can be resolved by limiting the wind real power generation $[28,29]$. The voltage will rise if the wind-based energy sources are connected to the secondary level of the distribution network because of the reverse power flow from sources to the utility grid. However, in normal conditions, the power flow is unidirectional from upstream (generation) to downstream (loads).

System constraints (both technical and economical) that need DG output power should be limited to the load demand and do not cause reverse power flow. However, in the case of violations, the power from wind-based energy sources becomes restricted and the sources need to be disconected from the low voltage network [30].

\subsubsection{Voltage Flicker}

Another drawback associated with variable wind power output is voltage flicker. It limits the maximum wind power generation. Grid-linked variable speed wind turbines are adversely affected by this issue because of wind density, speed variations and the wind tower shadow effects.

This issue also occurs in fixed speed wind turbines due to wake of the tower. During each cycle, the rotor blade crosses through the tower, resulting in reduction of the power output of the turbine. This produces periodical voltage and power fluctuations. However, fixed speed wind turbines are less critical compared to variable speed wind turbines [31].

\subsection{Unintentional Islanding}

Unintentional islanding is one of the principle technical problems for wind power generation. It happens when the main grid is disconnected from the system but the wind power continues to supply load. Due to some problems associated with islanding, it is necessary to apply some safety measures to overcome this issue [32]. Under islanding condition, there is no solid voltage and frequency reference to maintain the power system quality.

\subsection{Power Fluctuations in Grid}

The power output from wind sources is random and this creates disturbances in the grid level. These disturbances change the system parameters such as voltage and frequency, which ultimately affects the load side. To overcome these issues, power backup units such as battery, uninterruptible power supply (UPS) and generators are commonly used.

The power output from wind based energy source is influenced by the wind speed and the type of wind power unit. The power output of the same wind turbines under different wind conditions are shown in Figure 2.

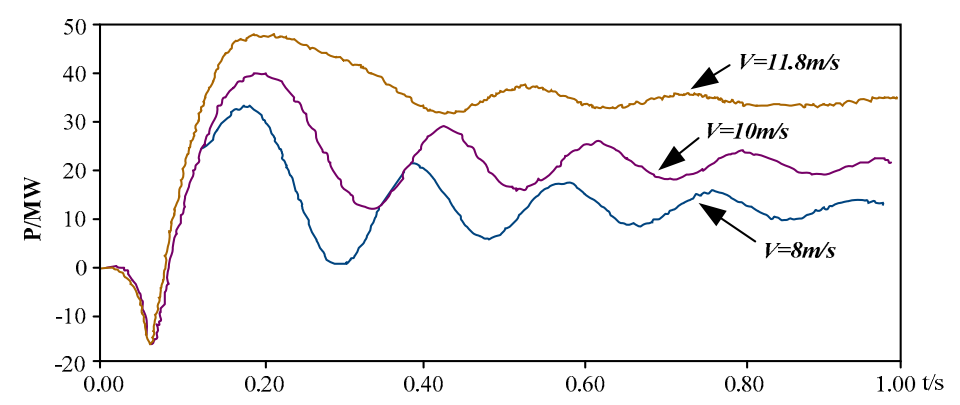

Figure 2. Output power generation by the same type of wind turbine during different wind speed. 
As shown in Figure 3, the output power varies from the wind turbines under the same wind condition [33].

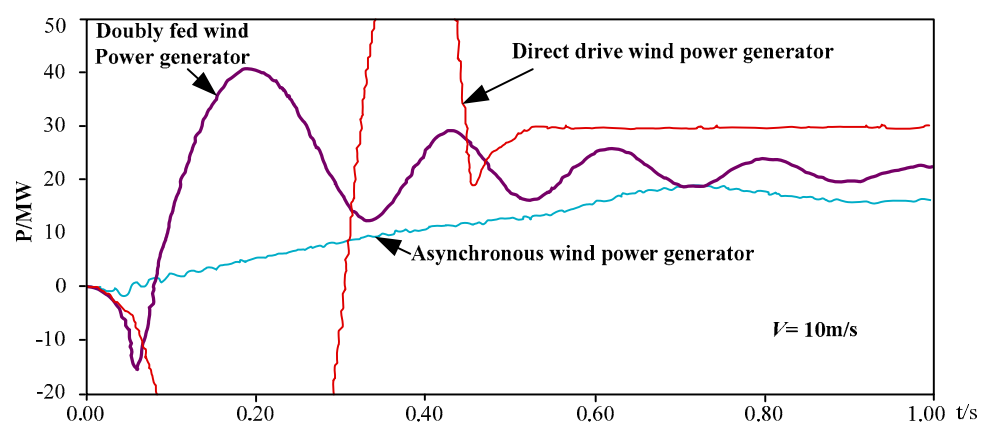

Figure 3. Power generation by different type of wind turbine during the same wind speed.

\subsection{Influence on Grid Frequency}

The distribution system is analyzed in terms of power quality and frequency is the ruling key factor in it. The frequency of the grid should be maintained within the prescribed limits. The increasing load demand tries to oppose the wind turbines at the generation plant and results in variations in the supply frequency. The varying wind speed influences the frequency of the power system and it is regulated by using pitch controllers and energy storage systems [34,35].

\section{Intermittent Smoothing Approaches for Wind Output}

To interconnect the wind-based energy sources with the power system, the ramp rate should be controlled within prescribed limits. If it exceeds the limits, the power quality of the grid will be badly affected. In addition, a ramp rate penalty will be imposed on the wind-based energy utility. The Electric Reliability Council of Texas (ERCOT) imposed a ramp rate penalty to a few wind-based power plants for violating ramp rate limits [36].

The ramp rate of wind-based energy sources is controlled by using smoothing methods. However, this will increase the overall system and operating costs. The smoothing methods are classified into two groups; (i) without utilization of energy storage devices and (ii) by utilizing energy storage devices [24,25]. The first group is based on pitch angle control [37] and the kinetic energy of inertia control [38]. These approaches require low expenditure and often fail to catch the maximum available wind power. The second category smoothen the wind power by using wind energy conversion systems (WECSs) and can catch the maximal amount of wind power. An example includes a 254-MWh NAS battery, which was installed to stabilize a 51-MW wind farm (WF) [39].

\subsection{Smoothing by Using Pitch Control}

The output power from wind-based energy sources depends on the pitch angle and the wind speed. The output power is directly proportional to the cube of wind speed [40]. Wind turbines work in two different operating regions based on wind speed: (i) weak wind speed and (ii) strong wind speed operating regions. In the weak wind speed operating region, the wind power is less than the rated output power. This problem can be resolved by capturing the maximum wind energy. In the strong wind speed operating region, the maximum power is obtained as the wind speed is higher than the rated speed. However, this will reduce the efficiency and requires a control mechanism for wind rotors. The pitch control of wind turbines is an efficient method to obtain the maximum power. It has an active control system to vary the pitch angle of the blade as shown in Figure 4. The rotational speed of a wind turbine depends on the torque produced by the blades and it can vary as the pitch angle changes. Burton et al. [40] used a classical pitch control system to control the rotor speed and obtained the rated power at high wind speed. 


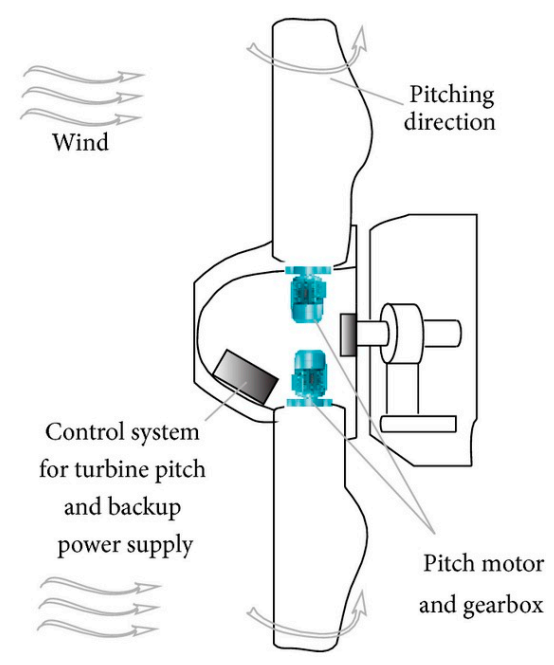

Figure 4. Pitch Control Wind Turbine.

The smoothing of the output power by the pitch angle using regulated generalized predictive control (GPC) is proposed in [41]. The GPC used the average and standard deviation of wind speed to smooth the output power. This mechanism is normally used for medium-to large-size wind turbine generators due to the low cost [42].

There are several other methods to control the pitch angle. The back-stepping [43] and feed-forward [44] methods are used if the wind speed is above the rated speed. A static and dynamic performance based wind turbine using Doubly Fed Induction Generator (DFIG) and pitch control algorithm is proposed in [45]. It smoothens the output power efficiently if the wind speed is higher than the rated speed. According to the authors in [46], smoothing the output power by alteration of blade pitch angle according to the wind speed is a dominant method, but wind turbine overall dynamics can be influenced in the case of malfunction of blade pitch control. Pitch regulated WT can smoothen the wind generator power until a certain limit of high wind speed and it should be stopped from operation above the limit $[47,48]$.

\subsection{Smoothing by Utilizing Energy Storage System}

Storage devices can reduce the uncertainty or power fluctuation of wind generation, shift the generation pattern, enhance flexibility, mitigate price hikes or sags and offer protection in the absence of wind power [49-51].

\subsubsection{Flywheel Energy Storage System}

Flywheels (FWs) can be used to store the wind energy in the form of kinetic energy that depends on the form, mass and rotational speed [52]. In charging mode, rotational motion is increased to store the energy as kinetic energy while in discharging mode, it discharges its kinetic energy. A Flywheel Energy Storage System (FESS) comprises of a machine, bearing and Power Electronic Interface (PEI) [53] as shown in Figure 5. 


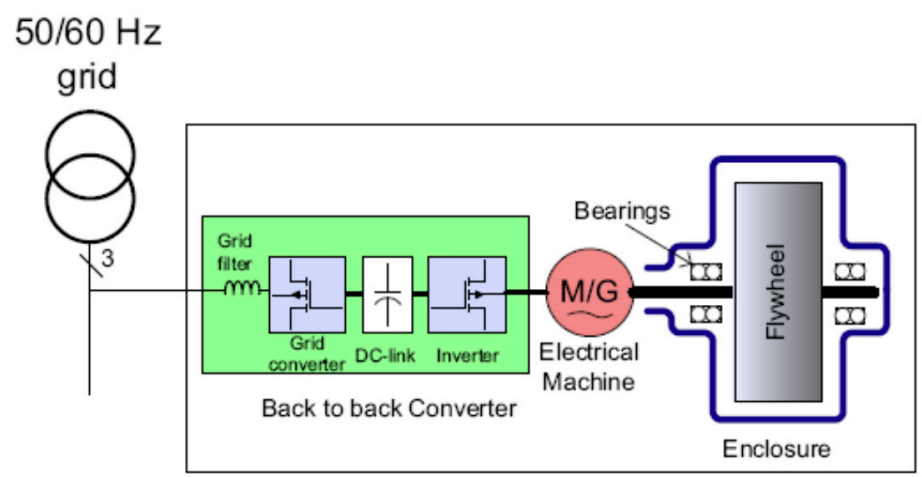

Figure 5. Components of the Flywheel Energy Storage System (FESS). Reprint with permission [53]; Copyright 2017, Elsevier.

The machine in the flywheel plays a vital role in storing the energy due to its electromechanical interface. Various types of machine used in the Flywheel Energy Storage Systems (FESSs) are induction machines (IMs), permanent magnet synchronous machines (PMSMs), homopolar machines (HMs), brushless direct current machines (BLDCMs), bearing less machines (BMs) and synchronous machines (SMs).

FESS suffers from bearing losses that can be reduced by designing it appropriately. Magnetic bearing like superconducting magnetic bearing (SMB), permanent (passive) magnetic bearing (PMB) and active magnetic bearing (AMB) are most widely used in FESS. Charging and discharging of FESS is done through power electronics; back-to-back (BTB) converters and AC-DC-AC configuration are normally used in FESS. Figure 6 shows an example of BTB configuration of flywheel (FW) connected to a common DC-link [54].

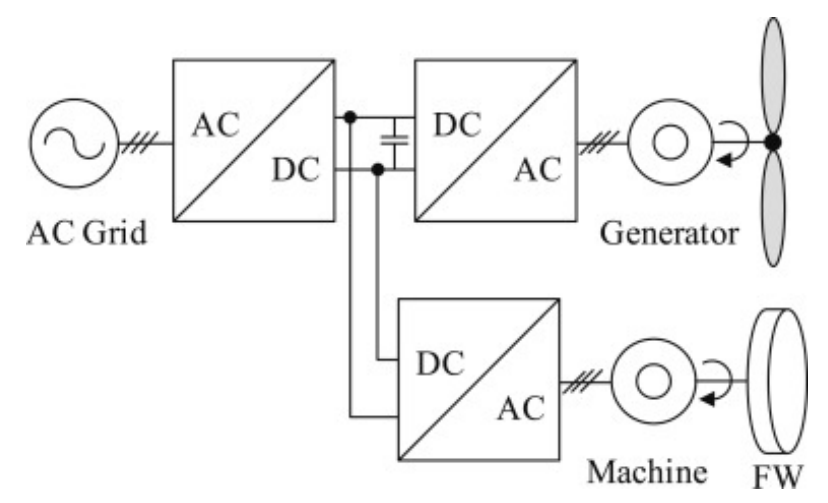

Figure 6. Back-to-back (BTB) plus DC-AC converter connected in DC-link. Reprint with permission [54]; Copyright 2006, IEEE.

FESSs have achieved popularity in wind power due to their quick reaction time and good dynamics. The first wind power plant using FW was developed in 1931 [53]. A FW adaptive generator injects active and reactive power to grid. Therefore, wind-based energy sources with FWs have less variation in grid voltage and output power [55]. A flywheel energy storage matrix system (FESMS) connected with a wind farm is proposed in [56]. It is noticed that a FESMS-dependent wind farm has the ability to suppress the power fluctuations caused by the oscillating wind speed.

The power interruptions due to cycling torque disturbance produced by wind turbines have been compensated by energy management algorithms depending on feedback control technologies [57]. Based on experimental findings, it was suggested that energy management algorithm can compensate the wind power fluctuations. FESSs can also be used as a short-duration energy storage system. 
Significant power quality advancement has been achieved in microgrids by using low speed flywheel energy storage systems [58].

Apart from controlling the intermittent power sources, FESSs can also be employed to regulate the frequency [59]. An isolated power system consisting of wind and FESS has been used to improve the frequency quality [60]. In [61], a thyristor controlled series compensator and flywheel energy storage (TCSC-FES) has been used to suppress the frequency and tie-line power flow variations caused by sudden load changes.

The integration of a multilevel control technique into the power system has been improved by the dynamic performance of a distribution static synchronous compensator (DSTATCOM) and FESS [62]. Suvire et al. [63] proved that the power quality during fault conditions can be improved by connecting a DSTATCOM at the junction point of common coupling (PCC) of the flywheel and wind source. The work in [64] consists of fuzzy logic and a special filter-based controlling technique. A fuzzy inference system (FIS) controls the active power of the DSTATCOM/FESS in conjunction with filter control of wind power fluctuations. An advanced and reliable management system for energy storage was achieved by an active power control system that is regulated by maintenance of wind power fluctuations without discharge or overload of storage devices. The FESS and WG produce a balanced power response compared to the system without FESS and power quality enhancement is based on the number of FWs.

An artificial neutral network that depends on a wind speed predictor has been designed in [65]. In it, the supervisory control unit (SCU) helps in appropriate management to store energy in a low capacity FESS. Furthermore, it optimizes the size of the Energy storage system (ESS) to reduce the system cost. Multiple FESS units included in a wind farm FESMS connection topology has been proposed in [66]. Each FESS unit is maintained by utilization of a neural-adaptive proportional integral derivative (PID) control algorithm that is also related to Lyapunov stability theory. It performed supportive operation among FESS to achieve voltage restoration, smooth power and quality regulation. The authors in [67] proposed a procedure for management of flywheel based on adaptive dynamic control which finds its application in small-signal models of wind turbine-FESS. It is utilized for reactive and active power stabilization from flywheel energy storage generated by wind turbines during both abnormal and normal operating conditions. They achieved power stability in a microgrid consisting of wind and flywheel by using an adaptive dynamic control. Flywheels are suitable for short term energy storage due to the higher losses from self-discharge. The estimated self-discharge per hour is $20 \%$ of the stored capacity [68]. Due to this drawback, alternate energy storage systems such as battery energy storage systems are promoted for power smoothing technologies and for long term energy storage.

\subsubsection{Battery Energy Storage System (BESS)}

Battery energy storage (BES) plays the same role as FWs to smooth the power. It is advantageous for long-term energy storage having minimum standby losses and high efficiency. It can respond rapidly in both charging and discharging modes. It consists of a number of batteries connected in series-parallel combinations for supplying the necessary power to the system. The basic part of a battery is its electrochemical cell, which is composed of a chemical electrolyte, positive electrode (anode) and a negative electrode (cathode). In discharge mode, an electrochemical reaction of the electrolyte takes place at the two electrodes, generating a flow of electrons from an external circuit. However, in charging mode, the electrical voltages are applied across the electrode to store energy in chemical form.

A wide range of batteries is used for BESS applications such as (i) valve regulated lead acid (VRLA); (ii) flooded lead acid (LA); (iii) vanadium redox (VRB); (iv) lithium ion (Li-ion); (v) sodium sulfur (NAS) and (vi) nickel cadmium (NiCd) batteries [69]. Amongst all these, lead acid batteries (LA) are the oldest and most extensively utilized for their mature technology, low cost and availability. However, high maintenance and regularly addition of distilled water limit their usage. VRLA batteries 
are an alternative as they use the same electrochemical technology as LA batteries with additional regulating valves and seals. VRLA batteries have better operating life compared to LA, require no maintenance and have an efficiency of $70-80 \%$. Furthermore, Li-ion, $\mathrm{NaS}$ and NiCd batteries hold the greater potential for future development and optimization. Li-ion batteries are smaller in size and low weight, with high energy density and storage efficiency close to $100 \%$. However, they have a high capital cost due to their complex structure. Sodium-sulfur (NaS) batteries are a superior option for BES power applications as they have more energy density, better life cycles and low maintenance cost.

Wind turbines generators combined with BES provide better power output and overcome the constraints of frequency deviations [70]. Wind generators and BES connected to the grid bus via voltage source converter (VSC) are shown in Figure 7.

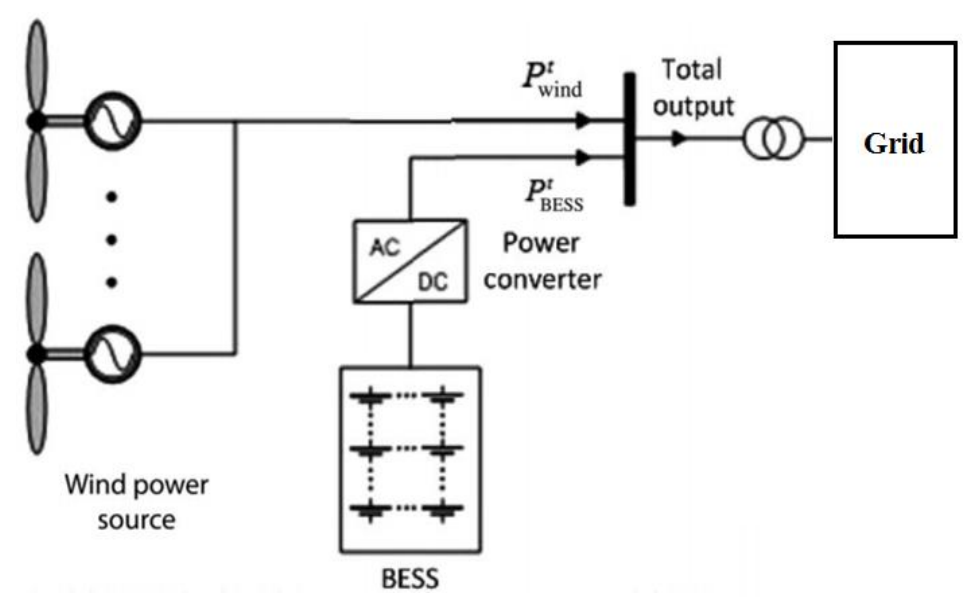

Figure 7. Battery energy storage system (BESS) for smoothing wind output connected to the grid. Reprint with permission [70]; Copyright 2016, IEEE.

It is significant to use the optimal size of BESS and a control strategy is required for BESS. A traditional feedback-based control scheme is highlighted in [71] for optimal use of BESS by considering its operating restrictions such as charge and discharge rate, state of charge (SOC) and lifetime. The proposed control scheme has successfully achieved smooth wind output power.

A coordinated operational dispatch scheme is suggested in [72] to minimize the power forecast error and to increase the life of a BESS. The optimal power capacity of the BESS is determined by a BESS capacity determination method using historical wind power data. The short-term dispatch of wind-BESS scheme mitigates the power fluctuations and stochastic nature of wind resources [72].

In [73], a semi-distributed BESS configuration is suggested for suppression of the wind output power fluctuations. The configuration consists of an aggregated BESS unit and a separate BESS unit at each individual wind turbine as shown in Figure 8. This configuration is effective for both wind profiles; wind turbines are situated nearby wind profiles and wind turbines are located far from each other with different wind profiles. The purpose of this configuration is to reduce the BESS capacity to minimize the total cost of the system. The BESS at each individual turbine partially reduces the wind power fluctuations and ultimately the total BESS receives less fluctuating power at its input. Therefore, power smoothing can be achieved at smaller capacity [73]. 


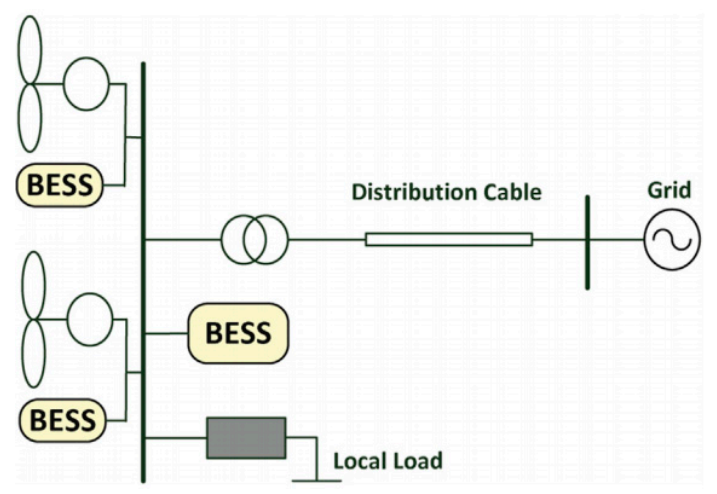

Figure 8. Semi-distributed BESS configuration. Reprint with permission [73]; Copyright 2014, Elsevier.

The output power of a wind farm cannot match the load demand due to uncontrollable wind speed. A bi-level control strategy is designed for wind-BESS microgrids, in which wide area power balance (WAPB) and NaS battery $\mathrm{V} / \mathrm{f}$ controls are used [74]. WAPB partially compensates power balance by load shedding, switching of wind turbines, pitch control of wind turbines per load requirement and ultra-short term forecast of wind power. The rest is compensated by NaS batteries with a voltage source converter (VSC)-based $\mathrm{V} / \mathrm{f}$ controller. This approach ensures efficient and stable operation of a wind-BESS microgrid [74].

A BESS dual-layer control action plan can mitigate wind power fluctuations while prolonging the battery lifecycle [75]. It comprises fluctuation mitigation and power allocation control layers. In the fluctuation mitigation control layer, fluctuations are mitigated by sending power instructions for the BESS through an adjustable first order low-pass filter (FLF). A particle swarm optimization (PSO) technique updates the time constant of FLF to reduce BESS capacity. The power allocation control layer allocates the power commands among the battery units in the BESS by using a mixed-integer quadratic programming (MIQP) model. The overcharge and discharge in the power allocation control layer helps to increase the lifecycle of the BESS [76-78].

A finite-time convergence robust control algorithm of a BESS to accommodate the fast-changing wind power generation and maintain a proper SOC level is proposed in [76]. A controller enables the BESS output power to follow its reference with high accuracy. In this control algorithm, a modified third order battery model is used as shown in Figure 9 [77]. In this model, parameter perturbations and other factors such as $\mathrm{R}_{1}$ (self-discharge resistance) and $\mathrm{R}_{0}$ (overcharge resistance) are used. The SOC of BESS is maintained in proper limits to smooth the power ramp without being overcharged or discharged [76].

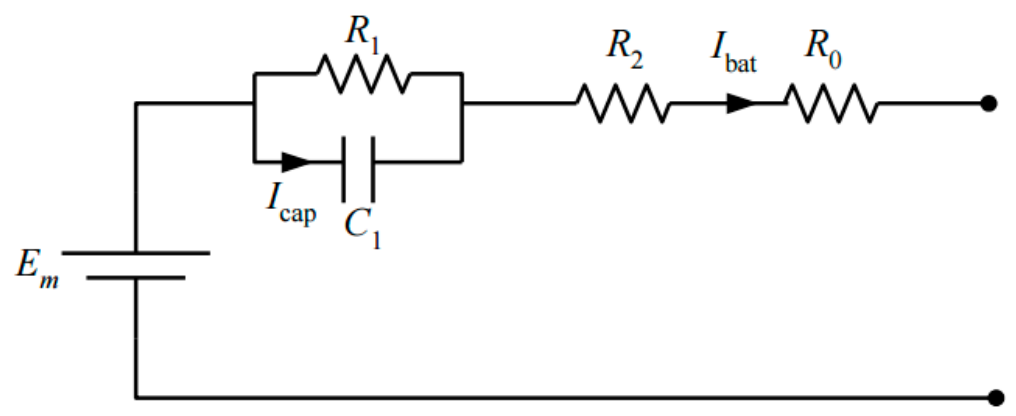

Figure 9. Simplified third order model of battery.

To update individual battery conditions in the BESS supporting a wind farm, a monotonic charging and discharging action plan is suggested [78]. It is observed that the optimal capacity of the battery decreases as their number expands in the BESS. The cost of a BESS depends on its capacity and it can be reduced by using more batteries but up to certain limits. It is noticed that the required 
capacity of BESS with four batteries is around $100 \mathrm{MWh}$ and it reduces to $60 \mathrm{MWh}$ if eight batteries are used. The two-fold benefits of this action plan lie in reducing the capital cost of the system by optimizing the capacity of each battery and prolonging their lifetime [78].

Miranda et al. in [79] focused on the arrangement and operation of islanded systems by integrating the BESS with high speed wind farms. A relative examination of the operational and high expenses of the islanded high speed wind energy system with and without the usage of the BESS is presented. It is concluded that BESS can effectively handle the problems caused by wind generation. The choice of the most appropriate battery type, its location and sizing is attained by this analysis during the planning stage.

A dual battery energy storage system (DBESS) to control the ramp rate of wind power with lower system operating cost is proposed in [80]. It comprises two battery storage systems, where one charges and the other discharges at the same time. Their charging-discharging roles are switched alternately on fully charge or discharge at a critical level. In this way, complete charge and discharge cycles are achieved, which extends the battery life and hence reduces the system operating cost. An optimal control algorithm is also expanded to manage short-term wind power forecast errors and make decisions for DBESS accordingly. In DBESS, hard switching limits its usage but this limitation can be removed by using a suitable control algorithm [80].

The reliability of power supply of the energy storage system (ESS)-linked model and wind turbine generator is presented in [81]. The authors linked a Monte Carlo Simulation (MCS) with the power system and developed an evaluation function to validate the significance of ESS in terms of reliability. MCS surpasses the stochastic performance of wind power and power failure of wind turbine generator in estimating the reliability indicate and calculating the sizes of BESS [82]. The maximum usage of the wind generation increases the system reliability and it is possible only with the usage of the BESS. BESS has a primary control reserve and the ability to absorb excessive power which increases the reliability of the wind system [83].

The reliability of wind-BESS and fuel cell-based system is expressed in terms of capacity value of energy storage (CVES) [84]. CVES is represented as the output power of wind turbines and the different properties of energy storage devices. CVES is helpful in determining suitable energy storage capacity allocation. The different factors which adversely affect the reliability are installed capacity of the wind turbine, maximum permissible energy stored, wind speed, temperature, the failure and the repair rate of BESS. The impact of each parameter is calculated in term of CVES to define the reliability [84].

\subsubsection{Superconductive Magnetic Energy Storage SYSTEM (SMESS)}

The superconductive magnetic energy storage (SMES) system is a relatively recent technology for storing energy in form of a magnetic field rather than batteries, which store energy via chemical reactions. DC current penetrates from a large superconducting coil at a cryogenic temperature and creates a magnetic field. The energy preserved in the magnetic field is the product of the self-inductance of the coil and the square of the DC electric current flowing through it [85].

Wind farms can replace fossil fuel and help abate $\mathrm{CO}_{2}$ emissions. However, they have less (fixed speed wind turbine) or no (variable speed wind turbine) inertial response to support the frequency of the system. This problem can be resolved by the virtual inertia provided by SMES [86].

The active and reactive power variations of the wind farm injected into the grid can effectively be stabilized by using SMES combined with damping controllers [87]. The efficiency of the suggested control action plan is enhanced by frequency- and time-domain approaches. The steady state analysis shows that SMES helps in smoothing power flow under different wind speed conditions. Furthermore, the transient analysis shows the effectiveness of SMES-based damping control system to suppress the bus voltage and active power fluctuations of the wind system. The varying torque condition, gust of wind and sudden load variations are the major causes of these fluctuations. 
SMES responds proficiently for energy storage and discharge. It maintains the power quality, reduces the wind power fluctuations and improves false ride-through capability for the grid-linked with wind farms. An SMES-based excitation system for a doubly-fed induction generator (DFIG) is proposed in [88]. The excitation system consists of a grid-side converter, DC chopper, SMES and rotor-side converter as shown in Figure 10. SMES is placed at the DC side of the two converters. The DC chopper controls the charging and discharging of the superconducting magnet. The power transfer among the superconductor, magnet and the generator rotor or the power grid is regulated by coordinating control of converters. SMES responds promptly for active and reactive power needs and compensates power in less than $5 \mathrm{~ms}$ [88].

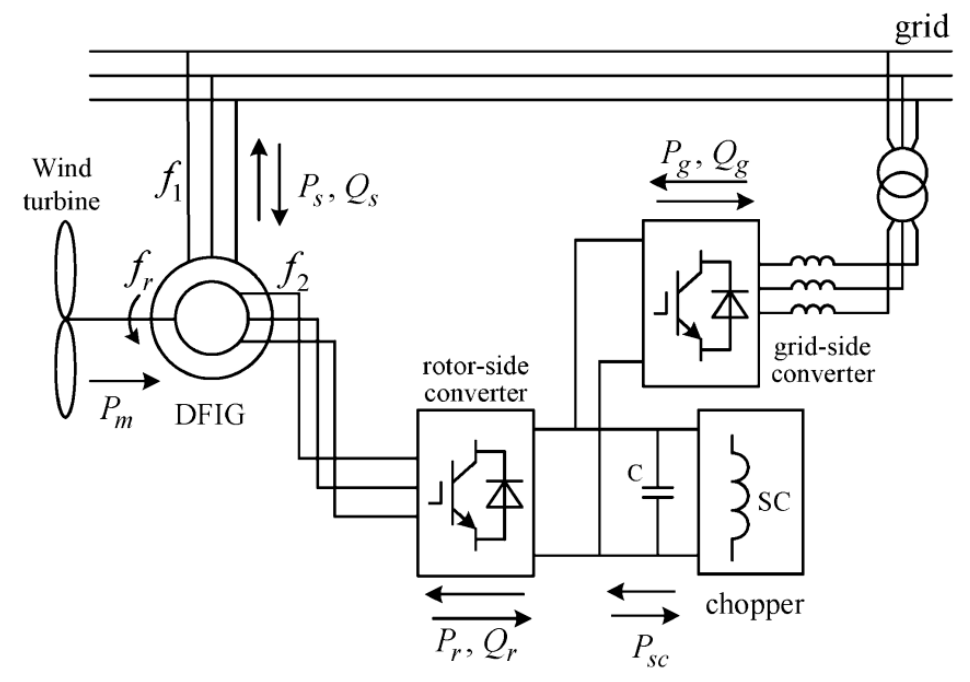

Figure 10. Configuration of doubly-fed induction generator (DFIG) wind power system based on superconductive magnetic energy storage (SMES). Reprint with permission [88]; Copyright 2011, IEEE.

The SMES is also used in multi-generator wind power systems to maintain the frequency at the nominal level [89]. The frequency fluctuations are minimized by increasing the capacity of the SMES. However, if immense size is utilized, its installation cost increases comparatively. A low pass filter (LPF) strategy is found efficient in smoothing the power with 30\% reduction of capacity of SMES [90]. The optimal coil size of SMES also reduces its installation cost without changing the stabilizing factor of power flow in interconnected power systems with wind farms [91]. The optimal coil sizes of SMES depend upon the reduction of the preliminary energy stored and tie-line power fluctuations. The optimization methods are effective, but they require complex computational analysis. A control strategy that depends upon a set-membership affine projection algorithm (SMAPA) is used in SMES as it provides rapid convergence and low computational difficulty [92]. SMAPA takes less time to charge and discharge the SMES and maintains the voltage by controlling a DC-DC chopper and voltage source converter at the PCC. Furthermore, SMES coils are fabricated with bridge joints, which cause loss in the form of Joule heat. A refined double pancake winding also known as "jointless double pancake coil winding" has been proposed to minimize the electrical losses due to high-temperature superconducting SMES coils [93].

SMESs are appropriate to smooth the output power due to their superior properties of high energy storage efficiency, short charge/discharge time, fast power exchange, no need for protection circuits such as batteries, no limitation of charging and discharging cycles, less maintenance, long life, less weight and damage proof against short circuit. However, they require high expenditures due to the need for a cryogenic system to keep the superconducting coil within the superconducting state $[92,93]$. 


\subsubsection{Ultra-Capacitor}

An ultra-capacitor, also defined as electric double-layer capacitor (EDLC) is a high-capacity capacitor. It differs in its inner structure fundamentally. In spite of containing two electrodes parted by an insulating layer, it has penetrable medium that induces the impact of a pair of plates with gigantic surface area, separated by only a few nanometers [92]. It has longer life and high efficiency due to the very small internal resistance (up to $0.12 \mathrm{~m} \Omega$ ) [94,95].

The use of ultra-capacitors with intermittent sources reduces the power fluctuations. Continuous Wind Speed Forecasting (CWSF) and charging and discharging modes of an ultra-capacitor are the key factors for wind power ramp rate control [96]. The pitch angle controller and online supervisory control (OSC) units are used to assist the ultra-capacitor charging and discharging modes.

An energy capacitor system (ECS) is utilized to reduce the ramp-rate of variable wind power generators connected to the grid [97]. It is a combination of EDLC and power electronic devices (IGBT, PWM VSC) as shown in Figure 11. The control systems selects he line power as a reference and follows it by discharging or absorbing active power to and from EDLC. ECS smoothen the power fluctuations and keeps terminal voltage to the required level by charging and discharging the EDLC. Moreover, a low pass filter is used to estimate the line power reference, which leads to enhanced system simplicity and cost effectiveness. The moving average (MA) method to generate line power reference by relating the wind power with the triangular wave is proposed in [98]. This method reduces capacitor size by $10 \%$ of its projected size. It consists of a complex circuit of adder, subtracter, summer and multiplier. However, due to its memory effect, energy storage is mal-operated even though it does not show any significant output power fluctuation [98].

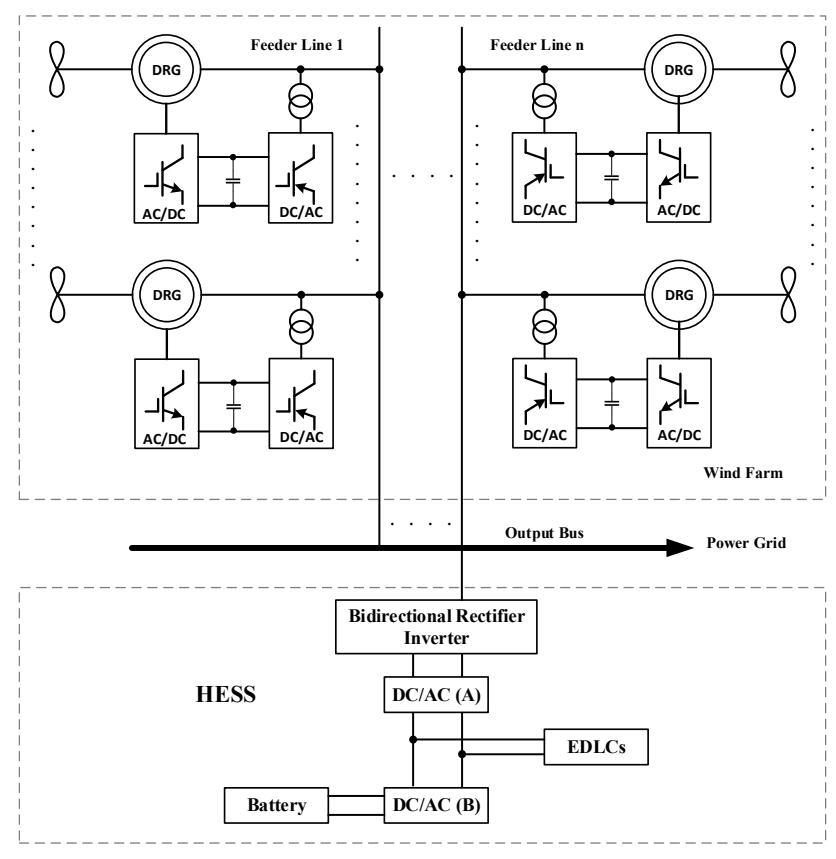

Figure 11. Power system consisting of wind power, electric double-layer capacitor (EDLC) and battery.

Both the high and low frequency elements of power fluctuations influence the performance of a power system. The high and low frequency elements of wind power can be smoothened by utilization of hybrid energy storage (HESS) systems comprised of batteries and EDLC [99]. In this proposed system, the high-frequency components are initially absorbed by the EDLC and the mean value of power from EDLC is further smoothened by the BESS. The EDLC plays a role in smoothing fast fluctuations because of its high power-density and slow fluctuations are smoothened by batteries due to their high energy-density. HESS-based wind power farms have better efficiency than others. However, they suffer from high capital cost [99]. 
The cooperative game model between ultra-capacitor and batteries is proposed in [100]. This model not only smoothens the power fluctuations but also reduces the cost of the system. The cost is reduced by minimizing the size, charging and discharging rates of the super-capacitors and batteries. A supercapacitor energy controller (SCEC) has been used to reduce the size of the ultra-capacitor in HESS [101]. Ultra-capacitors have long life, free maintenance and have energy effectiveness of $75-80 \%$ [95]. The principal pitfall of supercapacitors is their high cost, which is approximately five times higher than that of lead-acid batteries [102].

\subsection{Curtailment of Active Power by MPPT Control}

The output power fluctuations from wind generators can also be minimized by reducing the active power from them. In [28], the wind power is reduced when it is impossible to incorporate the maximum available power by the storage system and the load. The generator converter controls the shaft speed, extracting the maximum available power under normal condition and regulates the DC-link current. The curtailment coefficient to deflect the wind turbine (WT) operating point from the optimal maximum power point (MPP) characteristic is proposed in [29]. It reduces the wind turbine output power when the microgird (MG) frequency exceeds a certain limit $(50.5 \mathrm{~Hz})$. An energy management system (EMS) method consisting of a non-linear model predictive control (NMPC) action plan is suggested in [103]. It suppresses the active power of a DC microgrid consisting of PV, wind and BESS. A stochastic methodology for wind power curtailment in a power system is presented in [104]. It reduces line overloading risks and power flow distribution variability of power system having large scale wind power.

An integrated small-signal model for wind turbine utilizing two different MPPT control methods (tip speed ratio (TSR) control and optimal torque control (OTC) is proposed in [105]. The TSR procedure is a non-minimal phase and it allows a rapid reaction to wind speed variations. OTC has reduced transient actions but it shows better quality to smoothen output power than TSR. In OTC, the mechanical part performs the output power smoothing and there is no requirement for additional equipment to increase the generator output power smoothing. Moreover, it extracts the maximum power point in the case of wind speed variations.

A loss of $18 \%$ occurs in the total power if the ramp up/down limits are to 0.1 per unit per minute [106]. In [107], the dumping of wind power up to a certain limit is investigated by using the BES. They considered three cases; with fixed BES, without BES and with optimal BES capacity. It is observed that the cost of dumped generation was higher if smoothing is achieved by curtailment. The cost of dumped generation was $652,273 \$$ without batteries and US dollars 395,280 with batteries. Moreover, the curtailment of active power with optimal battery size is cost effective and has less standard deviation in the power output [107].

During full wind potential the cost of energy loss is usually higher when it is not harvesting in order to smooth the wind fluctuations. Therefore, it is recommended that the operation in this mode by MPPT be shortened. Hybrid models consisting of reducing power and energy storage improves the power smoothing and profit from wind farm [107].

\section{Control Strategy for BESS}

A high sized BESS is a costly alternative for dispatching renewable resources like wind and solar at a large-scale. A control strategy plan is necessarily required for optimal utilization of a BESS. In order to develop an effective control strategy for BES, a suitable battery model is required [108]. Battery modeling represents batteries in the form of an electronic circuit [51]. An accurate model does not utilize the BES fully because of its complex structure and large computational calculations. However, simple model is easy but less accurate. The battery model for BESS is proposed in [109]. This model is integrated with wind or PV by considering the charge rate, limit of charging/discharging and BES life time. This model consists of a closed loop optimal controller due to steady feedback received from the BES. This controller is simple in execution as it does not include mathematical 
equations, therefore, it requires less computation calculation time as compared to others while maintaining the SOC and current within the desired limits. The proposed controller can also be utilized as an alternative energy storage technology with the necessary rules [109].

The empirical mode decomposition (EMD) control procedure is used to keep the state of charge stable. It smoothens wind power using BESS [110]. The EMD filter decomposes the wind power $\left(\mathrm{P}_{\mathrm{w}}\right)$ into low and high frequency elements as shown in Figure 12. The low-frequency components are accessible as wind power for the grid-connected system and the high-frequency elements are collected by the BESS, which efficiently smoothens the output power. The EMD filter prolongs the battery life by adjusting the state of charge adaptively and helps overcome overcharging and discharging of BESS.

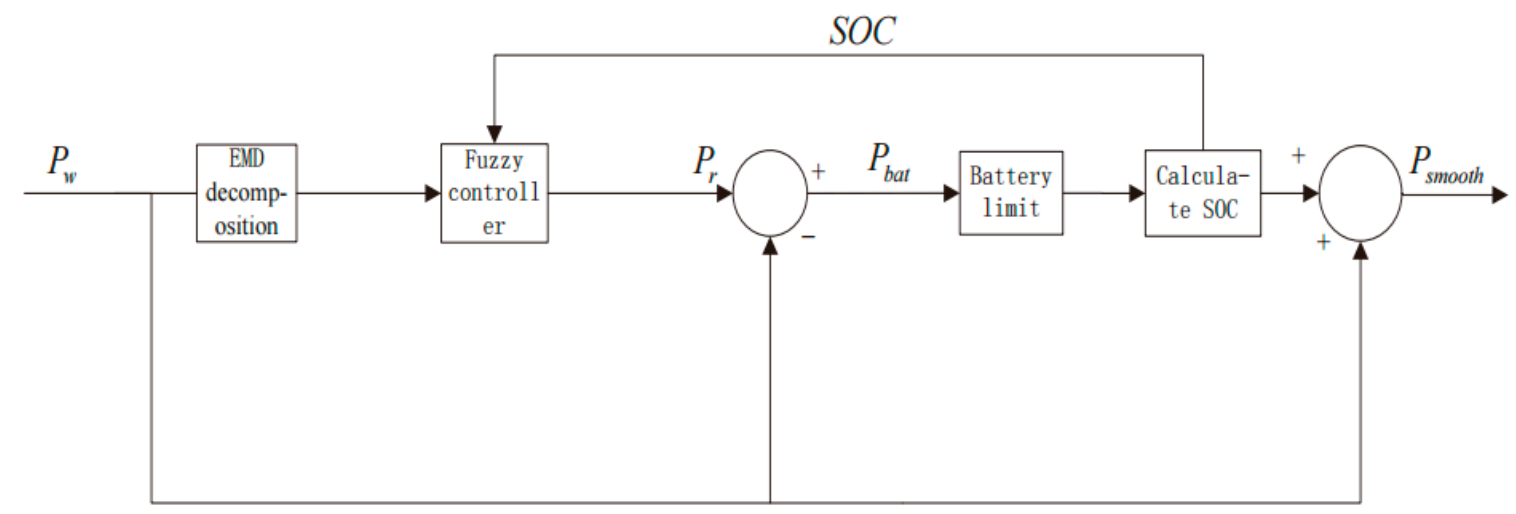

Figure 12. Empirical mode decomposition (EMD) based Control method with BESS.

A SOC real-time control module (SRCM) for BESS is proposed in [111], as shown in Figure 13, where $P_{B}$ is the power sent by BESS and $P_{\text {out }}$ is the practical power sent to the grid. In SRCM, a low-pass filter estimates the reference charging or discharging power of the BESS per output power from a wind farm. A fuzzy-logic-based time constant adjuster regulates the filter time constant to adjust the charging and discharging of power for BESS to alter the SOC within limits [111].

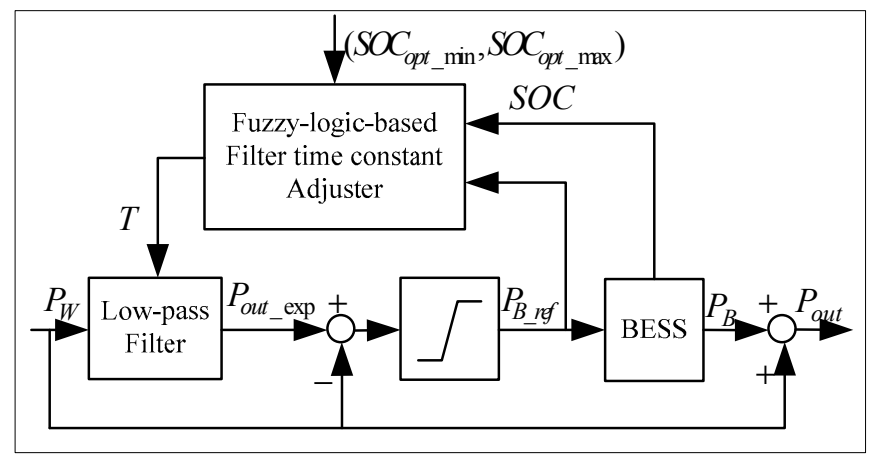

Figure 13. State of charge (SOC) real-time control module.

Statistical and economic cost models for determination of power and energy capacities of BESS are presented in [96]. Variable-interval reference signal optimization approach reduces the power deviation for the BESS capacity requirement and self-adaptive SOC control action plan that depends on fuzzy control theory helps to keep the SOC within limits. An improved PSO approach is used to find the minimum variance of power deviation as given in Equation (1). The maximum profit is calculated using Equation (2):

$$
\min M=\sum_{i=1}^{k} \frac{\sum_{t=t_{i-1}}^{t_{i}}\left|P_{t}^{w}-P_{i}^{r e f}\right|^{2}}{t_{i}-t_{i-1}}
$$




$$
\operatorname{Max} . B=\sum_{i=1}^{k} P_{i}^{r e f} \cdot \Delta T_{i} \cdot p r_{i}-\left(C_{f u n}+C_{s o c}^{p}+C_{\text {pow }}^{p}+C_{a d j}\right)
$$

The real and reactive power references of a battery energy storage system (BESS) are produced by $q-v$ and $p-f$ PI controllers for purpose of controlling the voltage and frequency of the system, respectively [112]. The performance of PI controller methods for BESS is unacceptable due to the system's nonlinear nature [112]. A robust nonlinear energy-based (EB) controller is used to overcome this issue [112]. The EB-based BESS control strategy is shown in Figure 14. EB consists of a d-q frame, which is used to simplify the controller. The EB controller takes the power reference as input and produces a duty ratio of the converter. The main objective of the converter is to control the current of the BESS. Although the performance of EB control is found to be more efficient than that of a PI controller, the common pitfall of the EB control process includes its greater design complexity, which hinders the application of EB control in power converters.

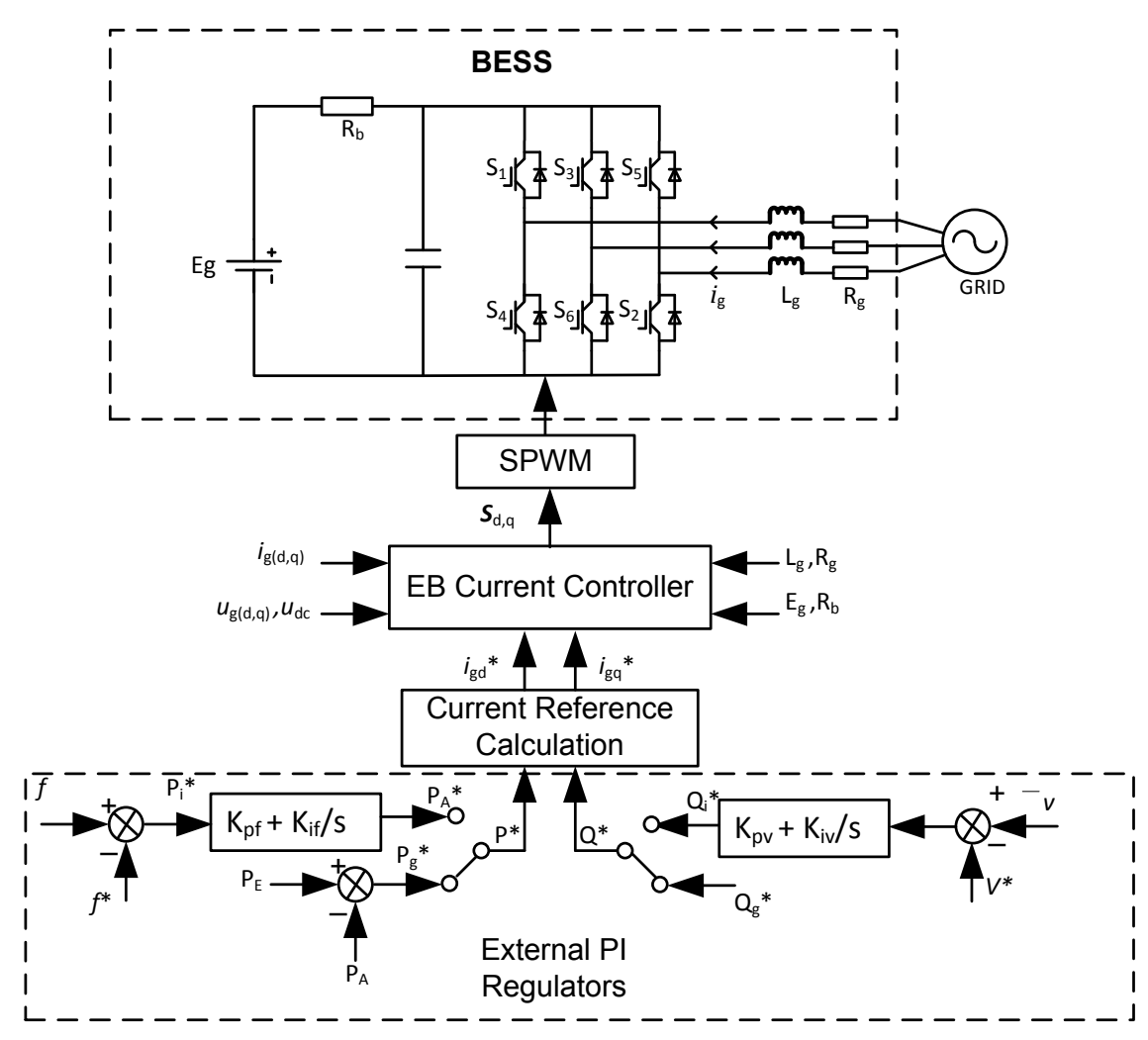

Figure 14. The topology of energy-based (EB) BESS control strategy.

In [113], the authors proposed a controlling action plan for smoothing wind and also to regulate PV power fluctuations by implementation of feedback control of SOC and a large-scale BESS. Power fluctuations are controlled effectively under the limit value of $10 \%$ per $15 \mathrm{~min}$. This control strategy manages BESS power and keeps SOC in a defined target region. A two-level control procedure was proposed in [114] to control the unreliability in forecast load and the estimated SOC levels of batteries. This control scheme handles unpredictability in load forecast and SOC calculation in both the scheduling and the real-time control phases.

\section{Discussion}

Wind output power curtailment is not preferred because it restricts the owners' profit but it is still considered as a key method that can smooth wind power output. Effects such as reverse power flow, voltage variation and frequency digression occur due to wind output variations that can be minimized 
by aiding wind with fast energy storage systems consisting of batteries and capacitors with better control. A comparison based on the performance among different mitigation methods is provided in Table 1.

Table 1. Comparison of characteristic features among different intermittent smoothing approaches for mitigating wind power variations.

\begin{tabular}{|c|c|c|c|c|c|}
\hline Characteristics & Pitch Control & Flywheel & Battery & Capacitors/SMES/EDLC & MPPT Method \\
\hline $\begin{array}{c}\text { Response time of } \\
\text { Intermittent } \\
\text { smoothing approach }\end{array}$ & Fast & Fast & Fast & Very Fast & Fast \\
\hline Energy Density & $\mathrm{N} / \mathrm{A}$ & Low & High & Low & N/A \\
\hline Power Density & N/A & High & High & High & N/A \\
\hline Life Period & Large & Very Large & Large & Large & Large \\
\hline $\begin{array}{l}\text { Ability to smooth fast } \\
\text { ups ramp and } \\
\text { downs ramp }\end{array}$ & Yes (ups ramp only) & Yes & Yes & Yes very fast & Yes \\
\hline $\begin{array}{l}\text { Efficiency in mitigating } \\
\text { short term } \\
\text { wind variation }\end{array}$ & High & High & High & High & High \\
\hline $\begin{array}{c}\text { Ability to mitigate } \\
\text { voltage/frequency variations }\end{array}$ & Yes & Yes & Yes & Yes & Yes \\
\hline Reliability & High & High & High & Very High & High \\
\hline Cost & Low & High & High & Very High & Low \\
\hline Size of wind farm & $\begin{array}{c}\text { few MW to large } \\
\text { MW scale }\end{array}$ & Large MW scale & $\begin{array}{l}0 \text { to large } \\
\text { MW scale }\end{array}$ & 0 to few MW scale & 0 to few KW scale \\
\hline
\end{tabular}

The performance comparison based on essential features reveals that MPPT control and pitch control are reliable methods but they have drawbacks for overcoming wind power fluctuations as it decreases the owner's profit. Energy storage systems consisting of batteries, capacitors or SMES are the most favorable options to overcome wind power fluctuation issues. Fast variations in wind power output may produce undesirable frequency or voltage oscillations at the PCC. These undesirable variations can be efficiently reduced with the use of battery or capacitor-based energy storage systems. Battery energy storage is considered as the most favorable for MW scale wind installations as it is found that batteries offer high energy density, helping to release power for larger period of times. On another aspect, flywheels and ultra-capacitors are high power density generators that will release power rapidly within seconds and can be employed to control power variations in small wind farms. In addition, capacitors/SMES/EDLC have great benefits over batteries because they are less costly, require less charging time and have longer life. This is why they are preferred for small wind installations at a commercial level. When considering capacitors or SMES, energy density increments proved to be a crucial limitation that restricts them for being applied in multi MW scale wind projects.

From this discussion, we can see that the energy storage in batteries is the most preferred option for resolving wind output power fluctuations for any size of wind turbine. Energy storage in battery form in most situations has to be incorporated along with wind turbine power converters, system operation and construction that depend mainly on the topology of the wind plant wind turbine types and control strategies. Operational restrictions such as: (i) charging rate limits; (ii) state of charge constraints; (iii) depth of discharge (DOD) restrictions; (iv) voltage limits and (v) current limits are important in limitation of batteries energy storage (BES). Recently, numerous steps that can promote the life cycles and efficiencies of available battery storage techniques have been adopted, which can also help to reduce overall capital expenditures. A synchronized operational dispatch scheme is suggested in [72], which can lessen the errors related to power forecast and boost the life of BESS. A semi-distributed BESS configuration is suggested to lessen the total expenditure of the BESS control system [73]. BESS dual-layer limitation plans are suggested to control wind power fluctuations while increasing the battery life cycle [75]. A definite time frame conjunction robust control algorithm of 
a battery energy storage system (BESS) is proposed for regular and even power ramp without being over-charged or discharged [76]. In [78], it is described that battery optimal capacity reduces as the number of batteries is higher in a BESS. It was suggested in [79] that a dual battery energy storage system can counter the ramp rate and wind power with lower system operating expenses.

Upon examination of the expenses of the various energy storage systems, the main expense for a battery system is somehow lesser as compared to flywheels but the operation and sustaining cost for the flywheel is less than for batteries. The utilization of flywheels is restricted to only multi MW scale wind farm and applying flywheel systems to overcome wind output power oscillations must be studied for small wind plants. It was also studied that the life cycle of flywheel system is better than that of batteries although they require more capital investment. However, it is still provident to install a flywheel system collateral with large wind farms for longer coverage.

\section{Conclusions and Future Recommendations}

This paper provides a comprehensive review of smoothing approaches for intermittent wind power output. The need for wind power smoothing approaches can be seen from the brief discussion of problems due to intermittent of wind power output when connected to the grid. From the reviews of various intermittent smoothing approaches, it is found that battery energy storage devices are more suitable in controlling the wind output power fluctuations provided the control strategy is effective.

Review of this paper also reveals the possible future research areas that can be explored for improving the intermittent smoothing approaches. These include new control strategies for battery storage, where modern control techniques such as fuzzy logic, predictive control and empirical mode decomposition control can be explored. Wind forecasting techniques are also a potential research area that will help in improving the intermittent approach in terms of technique and optimal battery sizing. Since the intermittent approach is commonly required in the energy management system, further works on improving EMS in terms of optimized economy design, size and efficiency of battery energy storage systems should be conducted as well.

Acknowledgments: The authors would like to thank the Government of Punjab, Pakistan for providing financial support under the research grant SSMS 2016. This research is also funded by University of Malaya under BKP special grant (Grant No. BKS061-2017).

Author Contributions: Muhammad Jabir, Safdar Raza, Hazlee Azil Illias and Hazlie Mokhlis has collected the information. Muhammad Jabir wrote the paper and improved it further with the feedback from Safdar Raza, Hazlee Azil Illias and Hazlie Mokhlis.

Conflicts of Interest: The authors declare no conflict of interest.

\section{References}

1. Ye, B.; Zhang, K.; Jiang, J.; Miao, L.; Li, J. Towards a 90\% renewable energy future: A case study of an island in the South China Sea. Energy Convers. Manag. 2017, 142, 28-41. [CrossRef]

2. International Energy Outlook. 2016. Available online: https://www.eia.gov/outlooks/ieo/electricity.php (accessed on 8 June 2017).

3. Ye, B.; Yang, P.; Jiang, J.; Miao, L.; Shen, B.; Li, J. Feasibility and economic analysis of a renewable energy powered special town in China. Resour. Conserv. Recycl. 2017, 121, 40-50. [CrossRef]

4. Islam, M.R.; Guo, Y.; Zhu, J. A High-Frequency Link Multilevel Cascaded Medium-Voltage Converter for Direct Grid Integration of Renewable Energy Systems. IEEE Trans. Power Electron. 2014, 29, 4167-4182. [CrossRef]

5. Shahbazi, M.; Poure, P.; Saadate, S.; Zolghadri, M.R. Five-leg converter topology for wind energy conversion system with doubly fed induction generator. Renew. Energy 2011, 36, 3187-3194. [CrossRef]

6. Bouzgou, H.; Benoudjit, N. Multiple architecture system for wind speed prediction. Appl. Energy 2011, 88, 2463-2471. [CrossRef]

7. Sideratos, G.; Hatziargyriou, N.D. Probabilistic Wind Power Forecasting Using Radial Basis Function Neural Networks. IEEE Trans. Power Syst. 2012, 27, 1788-1796. [CrossRef] 
8. Chow, T.W.S.; Xiao-Dong, L.; Yong, F. A real-time learning control approach for nonlinear continuous-time system using recurrent neural networks. IEEE Trans. Ind. Electron. 2000, 47, 478-486. [CrossRef]

9. Santamaría-Bonfil, G.; Reyes-Ballesteros, A.; Gershenson, C. Wind speed forecasting for wind farms: A method based on support vector regression. Renew. Energy 2016, 85, 790-809. [CrossRef]

10. Cassola, F.; Burlando, M. Wind speed and wind energy forecast through Kalman filtering of Numerical Weather Prediction model output. Appl. Energy 2012, 99, 154-166. [CrossRef]

11. Amjady, N.; Keynia, F.; Zareipour, H. Wind Power Prediction by a New Forecast Engine Composed of Modified Hybrid Neural Network and Enhanced Particle Swarm Optimization. IEEE Trans. Sustain. Energy 2011, 2, 265-276. [CrossRef]

12. Shukur, O.B.; Lee, M.H. Daily wind speed forecasting through hybrid KF-ANN model based on ARIMA. Renew. Energy 2015, 76, 637-647. [CrossRef]

13. Shi, J.; Ding, Z.; Lee, W.J.; Yang, Y.; Liu, Y.; Zhang, M. Hybrid Forecasting Model for Very-Short Term Wind Power Forecasting Based on Grey Relational Analysis and Wind Speed Distribution Features. IEEE Trans. Smart Grid 2014, 5, 521-526. [CrossRef]

14. Wang, S.; Zhang, N.; Wu, L.; Wang, Y. Wind speed forecasting based on the hybrid ensemble empirical mode decomposition and GA-BP neural network method. Renew. Energy 2016, 94, 629-636. [CrossRef]

15. Liu, H.; Tian, H.; Liang, X.; Li, Y. New wind speed forecasting approaches using fast ensemble empirical model decomposition, genetic algorithm, Mind Evolutionary Algorithm and Artificial Neural Networks. Renew. Energy 2015, 83, 1066-1075. [CrossRef]

16. Chowdhury, M.A.; Hosseinzadeh, N.; Shen, W.X. Smoothing wind power fluctuations by fuzzy logic pitch angle controller. Renew. Energy 2012, 38, 224-233. [CrossRef]

17. Gevorgian, V.; Booth, S. Review of PREPA Technical Requirements for Interconnecting Wind and Solar Generation; National Renewable Energy Laboratory: Golden, CO, USA, 2013.

18. Carvalho, P.M.S.; Correia, P.F.; Ferreira, L.A.F.M. Distributed Reactive Power Generation Control for Voltage Rise Mitigation in Distribution Networks. IEEE Trans. Power Syst. 2008, 23, 766-772. [CrossRef]

19. Guerrero, J.X.S.; Escriva, G. Simulation Model for Energy Integration of Distributed Resources in Buildings. IEEE Lat. Am. Trans. 2015, 13, 166-171. [CrossRef]

20. Ghorbanian, M.J.; Ahmadian, J.; Shams, S.; Goodarzvand, F.; Mahadi, W.N.L. Overview of grid connected doubly fed induction generator power quality. In Proceedings of the 2013 IEEE Conference on Clean Energy and Technology (CEAT), Langkawi TBD, Malaysia, 18-20 November 2013; pp. 146-151.

21. Barahona, B.; Sorensen, P.; Christensen, L.; Sorensen, T.; Nielsen, H.K.; Larsen, X.G. Validation of the Standard Method for Assessing Flicker From Wind Turbines. IEEE Trans. Energy Convers. 2011, 26, 373-378. [CrossRef]

22. Hu, W.; Chen, Z.; Wang, Y.; Wang, Z. Flicker Mitigation by Active Power Control of Variable-Speed Wind Turbines With Full-Scale Back-to-Back Power Converters. IEEE Trans. Energy Convers. 2009, 24, 640-649. [CrossRef]

23. Elnaggar, A.K.; Rueda, J.L.; Erlich, I. Comparison of short-circuit current contribution of Doubly-Fed induction generator based wind turbines and synchronous generator. In Proceedings of the 2013 IEEE Grenoble Conference, Grenoble, France, 16-20 June 2013; pp. 1-6.

24. Howlader, A.M.; Urasaki, N.; Yona, A.; Senjyu, T.; Saber, A.Y. A review of output power smoothing methods for wind energy conversion systems. Renew. Sustain. Energy Rev. 2013, 26, 135-146. [CrossRef]

25. Ould Amrouche, S.; Rekioua, D.; Rekioua, T.; Bacha, S. Overview of energy storage in renewable energy systems. Int. J. Hydrog. Energy 2016, 41, 20914-20927. [CrossRef]

26. Kinjo, T.; Senjyu, T.; Urasaki, N.; Fujita, H. Terminal-voltage and output-power regulation of wind-turbine generator by series and parallel compensation using SMES. IEE Proc. Gener. Transm. Distrib. 2006, 153, 276-282. [CrossRef]

27. Díaz-González, F.; Sumper, A.; Gomis-Bellmunt, O.; Villafáfila-Robles, R. A review of energy storage technologies for wind power applications. Renew. Sustain. Energy Rev. 2012, 16, 2154-2171. [CrossRef]

28. Alnasir, Z.; Kazerani, M. A dump load-less standalone wind energy conversion system supplying a generic load. In Proceedings of the 2016 IEEE Electrical Power and Energy Conference (EPEC), Ottawa, ON, Canada, 12-14 October 2016; pp. 1-7.

29. Serban, I. Small wind turbine control with frequency support for integration in microgrids. Bull. Transilv. Univ. Braşov Ser. I Eng. Sci. 2013, 6, 55. 
30. Sudhakar, P.; Malaji, S.; Sarvesh, B. Power Flow Analysis in a Wind Turbine Based Distributed Generation for Protection of a Power System. Int. J. Adv. Res. Technol. 2014, 3, 82.

31. Saad-Saoud, Z.; Jenkins, N. Models for predicting flicker induced by large wind turbines. IEEE Trans. Energy Convers. 1999, 14, 743-748. [CrossRef]

32. Petrone, G.; Spagnuolo, G.; Teodorescu, R.; Veerachary, M.; Vitelli, M. Reliability Issues in Photovoltaic Power Processing Systems. IEEE Trans. Ind. Electron. 2008, 55, 2569-2580. [CrossRef]

33. Shi, R.-J.; Fan, X.-C.; He, Y. Comprehensive evaluation index system for wind power utilization levels in wind farms in China. Renew. Sustain. Energy Rev. 2017, 69, 461-471. [CrossRef]

34. Lara-Jimenez, J.D.; Ramirez, J.M. Inertial frequency response estimation in a power system with high wind energy penetration. In Proceedings of the 2015 IEEE Eindhoven PowerTech, Eindhoven, The Netherlands, 29 June-2 July 2015; pp. 1-6.

35. Yoldaş, Y.; Önen, A.; Muyeen, S.M.; Vasilakos, A.V.; Alan, İ. Enhancing smart grid with microgrids: Challenges and opportunities. Renew. Sustain. Energy Rev. 2017, 72, 205-214. [CrossRef]

36. Zhao, J.; Abedi, S.; He, M.; Du, P.; Sharma, S.; Blevins, B. Quantifying Risk of Wind Power Ramps in ERCOT. IEEE Trans. Power Syst. 2017, PP, 1. [CrossRef]

37. Sruthi, M.A.; Sai, C.P.; Kumar, M.V. Controlling flicker caused due to power fluctuations by using individual pitch control for a variable speed dfig based wind turbine. Int. Res. J. Eng. Technol. 2017, 4, 286-293.

38. Abedini, A.; Mandic, G.; Nasiri, A. Wind power smoothing using rotor inertia aimed at reducing grid susceptibility. Int. J. Power Electron. 2008, 1, 227-247. [CrossRef]

39. Kawakami, N.; Iijima, Y.; Fukuhara, M.; Bando, M.; Sakanaka, Y.; Ogawa, K.; Matsuda, T. Development and field experiences of stabilization system using 34MW NAS batteries for a 51MW wind farm. In Proceedings of the 2010 IEEE International Symposium on Industrial Electronics, Bari, Italy, 4-7 July 2010; pp. 2371-2376.

40. Burton, T.; Sharpe, D.; Jenkins, N. Handbook of Wind Energy; John Wiley \& Sons: Hoboken, NJ, USA, 2001.

41. Senjyu, T.; Sakamoto, R.; Urasaki, N.; Funabashi, T.; Fujita, H.; Sekine, H. Output power leveling of wind turbine Generator for all operating regions by pitch angle control. IEEE Trans. Energy Convers. 2006, 21, 467-475. [CrossRef]

42. Ledesma, P.; Usaola, J. Doubly fed induction generator model for transient stability analysis. IEEE Trans. Energy Convers. 2005, 20, 388-397. [CrossRef]

43. Kanna, O.; Hanba, S.; Asato, S.; Yamashita, K. A method of stabilization of a wind generator power using backstepping algorithm. IEEJ Trans. Power Energy 1997, 117, 1513-1519. [CrossRef]

44. Matsuzaka, T.; Tuchiya, K. Study on stabilization of a wind generator power fluctuation. IEEJ Trans. Power Energy 1997, 117, 625-633. [CrossRef]

45. Belghazi, O.; Douiri, R.; Cherkaoui, M. Power control of a wind energy based on a DFIG by sliding mode approach and pitch angle optimal control by genetic algorithm. J. Achiev. Mater. Manuf. Eng. 2016, 74, 78-85. [CrossRef]

46. Lakshmi, K.V.; Srinivas, P. Fuzzy adaptive PID control of pitch system in variable speed wind turbines. In Proceedings of the 2014 International Conference on Issues and Challenges in Intelligent Computing Techniques (ICICT), Ghaziabad, India, 7-8 February 2014; pp. 52-57.

47. Jiang, Z.; Karimirad, M.; Moan, T. Dynamic response analysis of wind turbines under blade pitch system fault, grid loss, and shutdown events. Wind Energy 2014, 17, 1385-1409. [CrossRef]

48. Geng, H.; Yang, G. Linear and nonlinear schemes applied to pitch control of wind turbines. Sci. World J. 2014, 2014, 406382. [CrossRef] [PubMed]

49. Lu, M.S.; Chang, C.L.; Lee, W.J.; Wang, L. Combining the Wind Power Generation System with Energy Storage Equipments. In Proceedings of the 2008 IEEE Industry Applications Society Annual Meeting, Edmonton, AB, Canada, 5-9 October 2008; pp. 1-6.

50. Chen, H.; Cong, T.N.; Yang, W.; Tan, C.; Li, Y.; Ding, Y. Progress in electrical energy storage system: A critical review. Prog. Nat. Sci. 2009, 19, 291-312. [CrossRef]

51. Rekioua, D. Wind Power Electric Systems-Modeling, Simulation and Control; Springer: Bejaia, Algeria, 2014.

52. Nguyen, T.D.; Tseng, K.J.; Zhang, S.; Nguyen, H.T. A Novel Axial Flux Permanent-Magnet Machine for Flywheel Energy Storage System: Design and Analysis. IEEE Trans. Ind. Electron. 2011, 58, 3784-3794. [CrossRef]

53. Faraji, F.; Majazi, A.; Al-Haddad, K. A comprehensive review of Flywheel Energy Storage System technology. Renew. Sustain. Energy Rev. 2017, 67, 477-490. [CrossRef] 
54. Cimuca, G.O.; Saudemont, C.; Robyns, B.; Radulescu, M.M. Control and Performance Evaluation of a Flywheel Energy-Storage System Associated to a Variable-Speed Wind Generator. IEEE Trans. Ind. Electron. 2006, 53, 1074-1085. [CrossRef]

55. Awadallah, M.A.; Venkatesh, B. Energy Storage in Flywheels: An Overview. Can. J. Electr. Comput. Eng. 2015, 38, 183-193. [CrossRef]

56. Cao, Q.; Song, Y.D.; Guerrero, J.M.; Tian, S. Coordinated Control for Flywheel Energy Storage Matrix Systems for Wind Farm Based on Charging/Discharging Ratio Consensus Algorithms. IEEE Trans. Smart Grid 2016, 7, 1259-1267. [CrossRef]

57. Díaz-González, F.; Bianchi, F.D.; Sumper, A.; Gomis-Bellmunt, O. Control of a Flywheel Energy Storage System for Power Smoothing in Wind Power Plants. IEEE Trans. Energy Convers. 2014, 29, 204-214. [CrossRef]

58. Sebastián, R.; Peña-Alzola, R. Control and simulation of a flywheel energy storage for a wind diesel power system. Int. J. Electr. Power Energy Syst. 2015, 64, 1049-1056. [CrossRef]

59. Capp, F.W.; Lazarewicz, M.L.; Arseneaux, A.J.; Dresens, P.; Rojas, H.A. Methods, Systems and Apparatus for Regulating Frequency of Generated Power using Flywheel Energy Storage Systems with Varying Load and/or Power Generation. Patents EP2887485 A1, 24 June 2015.

60. Takahashi, R.; Tamura, J. Frequency control of isolated power system with wind farm by using Flywheel Energy Storage System. In Proceedings of the 2008 18th International Conference on Electrical Machines, Vilamoura, Portugal, 6-9 September 2008; pp. 1-6.

61. Deepak, M.; Abraham, R.J.; Gonzalez-Longatt, F.M.; Greenwood, D.M.; Rajamani, H.-S. A novel approach to frequency support in a wind integrated power system. Renew. Energy 2017, 108, 194-206. [CrossRef]

62. Suvire, G.O.; Mercado, P.E. Improvement of power quality in wind energy applications using a DSTATCOM coupled with a Flywheel Energy Storage System. In Proceedings of the 2009 Brazilian Power Electronics Conference, Bonito-Mato Grosso do Sul, Brazil, 27 September-1 October 2009; pp. 58-64.

63. Suvire, G.; Mercado, P. Combined control of a distribution static synchronous compensator/flywheel energy storage system for wind energy applications. IET Gener. Transm. Distrib. 2012, 6, 483-492. [CrossRef]

64. Suvire, G.; Mercado, P. Active power control of a flywheel energy storage system for wind energy applications. IET Renew. Power Gener. 2012, 6, 9-16. [CrossRef]

65. Islam, F.; Al-Durra, A.; Muyeen, S.M. Smoothing of Wind Farm Output by Prediction and Supervisory-Control-Unit-Based FESS. IEEE Trans. Sustain. Energy 2013, 4, 925-933. [CrossRef]

66. Lai, J.; Song, Y.; Du, X. Hierarchical Coordinated Control of Flywheel Energy Storage Matrix Systems for Wind Farms. IEEE/ASME Trans. Mechatron. 2017, PP, 99. [CrossRef]

67. Ghosh, S.; Kamalasadan, S. An Integrated Dynamic Modeling and Adaptive Controller Approach for Flywheel Augmented DFIG Based Wind System. IEEE Trans. Power Syst. 2017, 32, 2161-2171. [CrossRef]

68. Hadjipaschalis, I.; Poullikkas, A.; Efthimiou, V. Overview of current and future energy storage technologies for electric power applications. Renew. Sustain. Energy Rev. 2009, 13, 1513-1522. [CrossRef]

69. Divya, K.C.; Østergaard, J. Battery energy storage technology for power systems-An overview. Electr. Power Syst. Res. 2009, 79, 511-520. [CrossRef]

70. Liu, Y.; Du, W.; Xiao, L.; Wang, H.; Cao, J. A Method for Sizing Energy Storage System to Increase Wind Penetration as Limited by Grid Frequency Deviations. IEEE Trans. Power Syst. 2016, 31, 729-737. [CrossRef]

71. Teleke, S.; Baran, M.E.; Huang, A.Q.; Bhattacharya, S.; Anderson, L. Control Strategies for Battery Energy Storage for Wind Farm Dispatching. IEEE Trans. Energy Convers. 2009, 24, 725-732. [CrossRef]

72. Luo, F.; Meng, K.; Dong, Z.Y.; Zheng, Y.; Chen, Y.; Wong, K.P. Coordinated Operational Planning for Wind Farm With Battery Energy Storage System. IEEE Trans. Sustain. Energy 2015, 6, 253-262. [CrossRef]

73. Khalid, M.; Savkin, A.V. Minimization and control of battery energy storage for wind power smoothing: Aggregated, distributed and semi-distributed storage. Renew. Energy 2014, 64, 105-112. [CrossRef]

74. Luo, Y.; Shi, L.; Tu, G. Optimal sizing and control strategy of isolated grid with wind power and energy storage system. Energy Convers. Manag. 2014, 80, 407-415. [CrossRef]

75. Jiang, Q.; Gong, Y.; Wang, H. A Battery Energy Storage System Dual-Layer Control Strategy for Mitigating Wind Farm Fluctuations. IEEE Trans. Power Syst. 2013, 28, 3263-3273. [CrossRef]

76. Deng, Z.; Xu, Y.; Gu, W.; Fei, Z. Finite-time convergence robust control of battery energy storage system to mitigate wind power fluctuations. Int. J. Electr. Power Energy Syst. 2017, 91, 144-154. [CrossRef]

77. Teleke, S.; Baran, M.E.; Bhattacharya, S.; Huang, A.Q. Optimal Control of Battery Energy Storage for Wind Farm Dispatching. IEEE Trans. Energy Convers. 2010, 25, 787-794. [CrossRef] 
78. Savkin, A.V.; Khalid, M.; Agelidis, V.G. A Constrained Monotonic Charging/Discharging Strategy for Optimal Capacity of Battery Energy Storage Supporting Wind Farms. IEEE Trans. Sustain. Energy 2016, 7, 1224-1231. [CrossRef]

79. Miranda, I.; Silva, N.; Leite, H. A Holistic Approach to the Integration of Battery Energy Storage Systems in Island Electric Grids With High Wind Penetration. IEEE Trans. Sustain. Energy 2016, 7, 775-785. [CrossRef]

80. Nguyen, C.L.; Lee, H.H. A Novel Dual-Battery Energy Storage System for Wind Power Applications. IEEE Trans. Ind. Electron. 2016, 63, 6136-6147. [CrossRef]

81. Oh, U.; Choi, J.; Kim, H.-H. Reliability Contribution Function considering Wind Turbine Generators and Battery Energy Storage System in Power System. IFAC-PapersOnLine 2016, 49, 301-306. [CrossRef]

82. Sulaeman, S.; Yuting, T.; Benidris, M.; Mitra, J. Quantification of Storage Necessary to Firm up Wind Generation. IEEE Trans. Ind. Appl. 2017, PP. [CrossRef]

83. Acuña, L.G.; Padilla, R.V.; Mercado, A.S. Measuring reliability of hybrid photovoltaic-wind energy systems: A new indicator. Renew. Energy 2017, 106, 68-77. [CrossRef]

84. Shi, N.; Luo, Y. Energy storage system sizing based on a reliability assessment of power systems integrated with wind power. Sustainability 2017, 9, 395. [CrossRef]

85. Nielsen, K.E.; Molinas, M. Superconducting Magnetic Energy Storage (SMES) in power systems with renewable energy sources. In Proceedings of the 2010 IEEE International Symposium on Industrial Electronics, Bari, Italy, 4-7 July 2010; pp. 2487-2492.

86. Vitale, G. Frequency Stability Improvement in Weak Grids by Storage Systems. In Smart Energy Grid Design for Island Countries; Springer: Suva, Fiji, 2017; pp. 223-258.

87. Wang, L.; Chen, S.S.; Lee, W.J.; Chen, Z. Dynamic Stability Enhancement and Power Flow Control of a Hybrid Wind and Marine-Current Farm Using SMES. IEEE Trans. Energy Convers. 2009, 24, 626-639. [CrossRef]

88. Shi, J.; Tang, Y.; Xia, Y.; Ren, L.; Li, J. SMES Based Excitation System for Doubly-Fed Induction Generator in Wind Power Application. IEEE Trans. Appl. Supercond. 2011, 21, 1105-1108. [CrossRef]

89. Ali, M.H.; Tamura, J.; Wu, B. SMES strategy to minimize frequency fluctuations of wind generator system. In Proceedings of the 2008 34th Annual Conference of IEEE Industrial Electronics, Orlando, FL, USA, 10-13 November 2008; pp. 3382-3387.

90. Sheikh, M.R.I.; Mondol, N. Wind power smoothing scheme using SMES with reduced capacity. In Proceedings of the 2012 International Conference on Informatics, Electronics \& Vision (ICIEV), Dhaka, Bangladesh, 18-19 May 2012; pp. 404-410.

91. Saejia, M.; Ngamroo, I. Alleviation of Power Fluctuation in Interconnected Power Systems With Wind Farm by SMES With Optimal Coil Size. IEEE Trans. Appl. Supercond. 2012, 22, 5701504. [CrossRef]

92. Hasanien, H.M. A Set-Membership Affine Projection Algorithm-Based Adaptive-Controlled SMES Units for Wind Farms Output Power Smoothing. IEEE Trans. Sustain. Energy 2014, 5, 1226-1233. [CrossRef]

93. Kang, J.; Ko, T.K.; Al-Ammar, E.A.; Hur, K. Jointless Pancake Coil Winding for Minimizing Electrical Loss in HTS SMES for Wind Power. IEEE Trans. Appl. Supercond. 2015, 25, 1-5. [CrossRef]

94. Payman, A.; Pierfederici, S.; Meibody-Tabar, F. Energy control of supercapacitor/fuel cell hybrid power source. Energy Convers. Manag. 2008, 49, 1637-1644. [CrossRef]

95. Helwig, A.; Ahfock, T. Ultra-capacitor assisted battery storage for remote area power supplies: A case study. In Proceedings of the 2009 Australasian Universities Power Engineering Conference, Adelaide, Australia, 27-30 September 2009; pp. 1-6.

96. Aranizadeh, A.; Vahidi, B.; Rahiminejad, A. Wind turbine power output smoothing in microgrid using ultra-capacitor with continuous wind speed forecasting and online supervisory control. J. Renew. Sustain. Energy 2016, 8, 3. [CrossRef]

97. Islam, M.M.; Islam, A.; Shaikh, S.M.; Sheikh, M.R.I. Stability enhancement of wind power system by using energy capacitor system. In Proceedings of the 2015 International Conference on Electrical \& Electronic Engineering (ICEEE), Ankara, Turkey, 4-6 November 2015; pp. 85-88.

98. Muyeen, S.M.; Takahashi, R.; Ali, M.H.; Murata, T.; Tamura, J. Transient Stability Augmentation of Power System Including Wind Farms by Using ECS. IEEE Trans. Power Syst. 2008, 23, 1179-1187. [CrossRef]

99. Sun, B.; Liu, Z.; Yang, S.; Zhang, B. A Method in Smoothing Fluctuation of Wind Power with Wavelet Threshold Filtering and Mean-value Intervals by HESS. In Proceedings of the 2016 5th International Conference on Civil, Architectural and Hydraulic Engineering, Zhuhai, China, 30-31 July 2016. 
100. Han, X.; Zhao, Z.; Li, J.; Ji, T. Economic evaluation for wind power generation-hybrid energy storage system based on game theory. Int. J. Energy Res. 2017, 41, 49-62. [CrossRef]

101. Abeywardana, D.B.W.; Hredzak, B.; Agelidis, V.G.; Demetriades, G.D. Supercapacitor Sizing Method for Energy-Controlled Filter-Based Hybrid Energy Storage Systems. IEEE Trans. Power Electron. 2017, 32, 1626-1637. [CrossRef]

102. Kusko, A.; DeDad, J. Short-term, long-term, energy storage methods for standby electric power systems. In Proceedings of the Fourtieth IAS Annual Meeting, Conference Record of the 2005 Industry Applications Conference, Hong Kong, China, 2-6 October 2005; Volume 2674, pp. 2672-2678.

103. Kumar, A.S.; Ramakrishna, E.; Haq, S.S. A non-linear model predictive control (nmpc) energy management control strategy for standalone dc microgrids. Int. J. Core Eng. Manag. 2017, 135-147.

104. Koustas, G.; Van der Sluis, L.; Ummels, B.C.; Papaefthymiou, G. Stochastic assessment of opportunities for wind power curtailment. In Proceedings of the Nordic Wind Power Conference (NWPC2007), Roskilde, Denmark, 1-2 November 2007.

105. Nasiri, M.; Milimonfared, J.; Fathi, S.H. Modeling, analysis and comparison of TSR and OTC methods for MPPT and power smoothing in permanent magnet synchronous generator-based wind turbines. Energy Convers. Manag. 2014, 86, 892-900. [CrossRef]

106. Esmaili, A.; Nasiri, A. Power smoothing and power ramp control for wind energy using energy storage. In Proceedings of the 2011 IEEE Energy Conversion Congress and Exposition, Phoenix, AZ, USA, 17-22 September 2011; pp. 922-927.

107. Alanazi, A.; Khodaei, A.; Babazadeh, H. Power fluctuation reduction in wind turbine generator systems. In Proceedings of the 2016 North American Power Symposium (NAPS), Denver, CO, USA, 18-20 September 2016; pp. 1-5.

108. Shivashankar, S.; Mekhilef, S.; Mokhlis, H.; Karimi, M. Mitigating methods of power fluctuation of photovoltaic (PV) sources-A review. Renew. Sustain. Energy Rev. 2016, 59, 1170-1184. [CrossRef]

109. Teleke, S.; Baran, M.E.; Bhattacharya, S.; Huang, A.Q. Rule-Based Control of Battery Energy Storage for Dispatching Intermittent Renewable Sources. IEEE Trans. Sustain. Energy 2010, 1, 117-124. [CrossRef]

110. Xiyun, Y.; Chao, C.; Xiangjun, L.; Tingting, Y. Control method of smoothing wind power output using battery energy storage system based on empirical mode decomposition. In Proceedings of the 2015 34th Chinese Control Conference (CCC), Hangzhou, China, 28-30 July 2015; pp. 304-308.

111. Zou, J.; Peng, C.; Shi, J.; Xin, X.; Zhang, Z. State-of-charge optimising control approach of battery energy storage system for wind farm. IET Renew. Power Gener. 2015, 9, 647-652. [CrossRef]

112. Hou, R.; Nguyen, T.-T.; Kim, H.-M.; Song, H.; Qu, Y. An Energy-Based Control Strategy for Battery Energy Storage Systems: A Case Study on Microgrid Applications. Energies 2017, 10, 215. [CrossRef]

113. Li, X.; Hui, D.; Lai, X. Battery Energy Storage Station (BESS)-Based Smoothing Control of Photovoltaic (PV) and Wind Power Generation Fluctuations. IEEE Trans. Sustain. Energy 2013, 4, 464-473. [CrossRef]

114. Kim, S.K.; Kim, J.Y.; Cho, K.H.; Byeon, G. Optimal Operation Control of Multiple BESSs for a Large-Scale Customer under Time-Based Pricing. IEEE Trans. Power Syst. 2017, PP, 1. [CrossRef]

(c) 2017 by the authors. Licensee MDPI, Basel, Switzerland. This article is an open access article distributed under the terms and conditions of the Creative Commons Attribution (CC BY) license (http:// creativecommons.org/licenses/by/4.0/). 